\title{
Which skills protect graduates against a alack labour market?
}

Citation for published version (APA):

Humburg, M., de Grip, A., \& van der Velden, R. K. W. (2012). Which skills protect graduates against a alack labour market? METEOR, Maastricht University School of Business and Economics. METEOR Research Memorandum No. 002 https://doi.org/10.26481/umamet.2012002

Document status and date:

Published: 01/01/2012

DOI:

10.26481/umamet.2012002

Document Version:

Publisher's PDF, also known as Version of record

\section{Please check the document version of this publication:}

- A submitted manuscript is the version of the article upon submission and before peer-review. There can be important differences between the submitted version and the official published version of record.

People interested in the research are advised to contact the author for the final version of the publication, or visit the DOI to the publisher's website.

- The final author version and the galley proof are versions of the publication after peer review.

- The final published version features the final layout of the paper including the volume, issue and page numbers.

Link to publication

\footnotetext{
General rights rights.

- You may freely distribute the URL identifying the publication in the public portal. please follow below link for the End User Agreement:

www.umlib.nl/taverne-license

Take down policy

If you believe that this document breaches copyright please contact us at:

repository@maastrichtuniversity.nl

providing details and we will investigate your claim.
}

Copyright and moral rights for the publications made accessible in the public portal are retained by the authors and/or other copyright owners and it is a condition of accessing publications that users recognise and abide by the legal requirements associated with these

- Users may download and print one copy of any publication from the public portal for the purpose of private study or research.

- You may not further distribute the material or use it for any profit-making activity or commercial gain

If the publication is distributed under the terms of Article $25 \mathrm{fa}$ of the Dutch Copyright Act, indicated by the "Taverne" license above, 


\section{Maastricht University}

Martin Humburg, Andries de Grip, Rolf van der Velden

Which skills protect graduates against a slack labour market?

RM/ 12/002

\section{METEOR}

Maastricht University School of Business and Economics

Maastricht Research School of Economics

of Technology and Organization

\section{P.O. Box 616}

NL - 6200 MD Maastricht

The Netherlands 


\title{
Which skills protect graduates against a slack labour market?
}

\author{
Martin Humburg, ${ }^{* 1}$ Andries De Grip, ${ }^{*}$ Rolf Van Der Velden ${ }^{*}$ \\ *Research Centre for Education and the Labour Market, Maastricht University, 6200MD Maastricht, \\ The Netherlands \\ ${ }^{\ddagger}$ IZA, Bonn
}

\begin{abstract}
This paper explores the relationship between graduates' skill levels and the risk of overeducation and unemployment in 17 European countries. We distinguish between field-specific and general skills and between two labour market segments, the occupational domain of a particular field of study and the labour market segment which requires general skills. In line with the predictions of the crowding out hypothesis, we find that the level of protection afforded by fieldspecific skills against the risk of overeducation increases with the degree of excess labour supply in the occupational domain of the graduate's field of study. Conversely, general skills offer more protection against the risk of overeducation when excess labour supply in the labour market segment which requires general skills is higher. Field-specific skills also protect graduates against the risk of unemployment, whereas graduates' level of general skills appears to be unrelated to the risk of becoming unemployed.
\end{abstract}

\footnotetext{
${ }^{1}$ Corresponding author. E-Mail: m.humburg@maastrichtuniversity.nl

This paper and its other versions have benefited from discussions at the $2^{\text {nd }}$ ELM Conference at Maastricht University, as well as at the 2010 IAB PhD workshop in Nuremberg. The authors are grateful to Jim Allen and Arnaud Dupuy for their useful comments. Any errors or inaccuracies are, of course, the sole responsibility of the authors.
} 


\section{Introduction}

Several studies analyse the cyclical crowding out of low-skilled workers by high-skilled workers (Gautier et al., 2002; Devereux, 2002; Gesthuizen and Wolbers, 2010; Keane and Prasad, 1993; Pollmann-Schult, 2005; Teulings and Koopmanschap, 1989; Van Ours and Ridder, 1995). In general, their findings suggest that having a higher level of education protects workers against unemployment in slack labour markets: when overall labour demand decreases, higher-educated workers will enter the jobs previously occupied by lower-educated workers and these in turn will end up unemployed. While previous studies focus on workers with different levels of education, we expect the same mechanisms to lead to competition for jobs among workers with the same level of education but different skill endowments. Workers with the lowest skill endowments within their level of education are most likely to be crowded out when excess labour supply increases. To our knowledge, this study is the first to focus on individuals with the same level of education with respect to whether the protective effect of a higher level of skills against overeducation and unemployment increases with the degree of excess supply in the labour market. For our analysis, we use data from a graduate ${ }^{2}$ survey conducted in 17 European countries; these data contain skill measures and offer variation in labour market conditions across countries and fields of study. We examine whether the extent to which graduates' labour market risks are affected by fluctuations in the labour supply-demand ratio depends on graduates' field-specific and general skills. By focusing on individuals at the upper end of the educational distribution around the time of their entering the labour market, we are able to distinguish two risks associated with excess labour supply: the risk of overeducation and the risk of unemployment. ${ }^{3} \mathrm{We}$ examine field-specific and general skills because these represent one of the most important skills dichotomies. ${ }^{4}$

\footnotetext{
${ }^{2}$ Throughout this paper, graduates refer to individuals who have been the subject of a graduation from a higher education institution, including both universities and universities of applied sciences.

${ }^{3} \mathrm{We}$ do not include wages in our analysis as wages of labour market entrants are strongly institutionalized and depend little on skills.

${ }^{4}$ Economic literature usually distinguishes between firm-specific and general skills. While the former augment productivity only in a specific firm, the latter are productive in multiple firms. In our analysis of labour market outcomes of graduates, the unit of analysis is the field of study rather than the firm. Following Heijke et al. (2003), we therefore
} 
This paper contributes to the literature in two ways. First, we shed more light on the relationship between field-specific and general skills and the labour market outcomes of graduates. Second, we analyse how the protective effect of field-specific and general skills varies with changes in the supply and demand ratio. Our findings particularly add to the literature on heterogeneous skill within education levels (e.g., Allen and Van der Velden, 2001; Green and McIntosh, 2002) as well as to the literature on the incidence and determinants of overeducation among graduates in light of higher education expansion (e.g., Battu et al., 1999; Battu and Sloane, 2000; Chevalier, 2003; Di Pietro and Urwin, 2006; Dolton and Vignoles, 2000; McGuinness, 2003, McGuinness and Sloane, 2010; Sloane et al., 1996,1999; Verhaest and Van der Velden, 2010).

In line with the predictions of the crowding out hypothesis, we find that the level of protection field-specific skills offer against the risk of overeducation increases with the degree of excess labour supply in the occupational domain of the graduate's field of study. Conversely, general skills offer more protection against the risk of overeducation when excess labour supply in the labour market segment which requires general skills is higher. Further, field-specific skills also protect graduates against the risk of unemployment, whereas graduates' level of general skills appears to be unrelated to the risk of unemployment.

The remainder of this paper is structured as follows: Section 2 presents the conceptual framework and our hypotheses. In Section 3 we discuss our data, and in Section 4 we present our estimation results. Section 5 then sets forth our conclusions.

\section{Conceptual framework and hypotheses}

The crowding out hypothesis is compatible with the job competition model (Thurow, 1975) and is based on the idea that when jobs become scarce, vacancies previously filled with low-skilled

deviate from the standard dichotomy by referring to field-specific instead of firm-specific skills. We define field-specific skills as skills which are productive in jobs related to a graduate's field of study and which are transferable to the occupational domain of other fields of study only with considerable value depreciation. General skills, on the other hand, are productive in all occupational domains and do not depreciate when transferred from one domain to another. 
workers are filled with higher skilled workers, pushing the former into ever lower skilled jobs or even into unemployment. This process is also referred to as skill bumping (Borghans and De Grip, 2000) and is likely to intensify with the degree of excess labour supply. There are several studies supporting this hypothesis. Devereux (2002) finds that the mean level of education of those employed in a particular occupation increases during recessions in the US. Keane and Prasad (1993) show that workers with college degrees were protected from cyclical variation in employment in the US in the 1970s. Pollmann-Schult (2005) finds evidence for crowding out in Germany in the period 1984-2000. For the Dutch labour market, Teulings and Koopmanschap (1989) find evidence for crowding out of workers with lower levels of education by workers with higher levels of education during the recession of the 1980s. For the 1990s, Van Ours and Ridder (1995), and similarly Gautier et al. (2002) suggest that crowding out might have been limited to university-educated versus high-vocational-educated workers. Gesthuizen and Wolbers (2010) argue that over the period 1980-2004 in the Netherlands, crowding out resulted from higher education expansion rather than economic shocks.

The above-mentioned studies analysing cyclical crowding out define skills as years of schooling or level of education. In our analysis, we use direct (self-assessed) skill measures at the individual level. We are therefore able to examine what happens to the risk of overeducation and the risk of unemployment of graduates from higher education with different skill endowments when an economic or demographic shock hits the labour market. We distinguish two types of skills, fieldspecific skills and general skills. These skill types have been shown to affect labour market entrants' risk of overeducation as well as their risk of unemployment. Studies on labour market entrants at the intermediate education level emphasize the relevance of field-specific skills for labour market success (Bishop, 1995; Campbell and Laughlin, 1991; Goux and Maurin, 1994; Kang and Bishop, 1989; Mane, 1999; Payne, 1995; Ryan, 2001). Non-college bound high school students with field-specific skills have a smoother transition into work and higher earnings than their more generally educated counterparts. The situation may differ for higher-educated graduates. Heijke et 
al. (2003) show that both field-specific and general skills affect the labour market outcomes of graduates. High field-specific skills increase graduates' chances of getting a job in occupations related to their own field of study, which is on average associated with higher wages. General skills, on the other hand, increase graduates' probability of receiving training during their first years in the labour market, which is also associated with higher wages. Both skill types, these authors conclude, therefore positively impact wages: field-specific skills by securing a job related to the field of study, and general skills by increasing the incidence of training. Verhaest and Van der Velden (2010), however, find that graduation from a study programme which is more focused on general skills significantly increases the probability of being overeducated in the first job. But graduating from such general programmes also increases the probability to 'escape' from a situation of overeducation and finding a job which matches the level of education. In a study on graduates in the UK, Chevalier and Lindley (2009) find that vocational courses protect graduates against 'genuine' overeducation. ${ }^{5}$ But these authors also find that a general skill, like mathematics, protects graduates against overeducation. We therefore conclude that the relevance of field-specific skills which is so clear-cut for the labour market success of non-college bound high school students is not necessarily transferable to graduates.

In addition to distinguishing two types of skills, we differentiate between two labour market domains: the specific labour market for a field of study and the labour market segment which requires general skills (the 'general labour market'). Specific labour markets refer to multiple, mutually exclusive occupational domains related to particular fields of study. We argue that graduates' prospects in the occupational domain related to their field of study are based on their level of field-specific skills. This labour market segment includes occupations which require a very specific set of skills, such as medical doctors, pilots, or engineers. In the occupational domain of a particular field of study, field-specific skills are the dominant factor for labour market success,

\footnotetext{
${ }^{5}$ Chevalier and Lindley (2009) define individuals as being genuinely overeducated when they do not work in a traditional graduate occupation and are unsatisfied with the match between their job and their education.
} 
because these are instantly deployable and are associated with low costs for further field-specific training. Alternatively, graduates have the choice to work in the general labour market when they are not able to find employment in the occupational domain related to their field of study. The general labour market segment contains occupations which require graduates to have broadly applicable skills, such as the ability to think analytically. In the general labour market, competition for jobs is not limited to graduates of particular fields of study. Rather, all graduates can compete for these jobs. We argue that graduates' prospects in the general labour market are based on their general skills. This is because graduates' specific skills are not transferable to this segment. Examples of general jobs are trainee programmes in large firms, management positions, and general administrative positions.

When unemployment is average, there will still be some level of job-worker mismatch in terms of overeducation, and a graduate's risk of becoming one of these mismatched workers will certainly depend on the level of skill. We therefore expect graduates with high levels of field-specific or general skills to have a lower risk of becoming overeducated than graduates with low levels of these skills (hypothesis 1 ).

The distinction between a labour market where more field-specific skills are required and a labour market where more general skills are required has important implications for the formulation of our hypotheses with regard to the consequences of supply and demand shocks. Shocks taking place in the field-specific labour market will affect the relationship between field-specific skills and labour market outcomes, whereas shocks in the general labour market will affect the relationship between general skills and labour market outcomes. When the number of graduates in a particular field of study increases relative to the number of graduate jobs at the tertiary level in the occupational domain related to this field, given an economic and/or demographic shock, more graduates with low levels of field-specific skills will be forced to take up jobs previously available for workers with intermediate qualifications for that field. The higher the excess labour supply in the field-specific labour market, the greater the difference will be in the risk of overeducation 
between graduates with high and graduates with low field-specific skills. We therefore expect the protective effect of field-specific skills against overeducation to increase with the degree of excess supply of graduates in the field-specific occupational domain (hypothesis 2).

In the general labour market, employers prefer workers with the highest general skills available. Therefore, graduates with lower levels of general skills will accept jobs previously available for workers with intermediate levels of education when jobs which require higher education become scarce. We therefore expect to observe an increase in the protective effect of general skills against overeducation when unemployment and competition for jobs in the general labour market increase (hypothesis 3).

Let us now turn to the risk of unemployment. According to a strict interpretation of the crowding out hypothesis, individuals with higher levels of education always possess higher and more productive skills than workers with lower levels of education. It will therefore always be attractive for firms to hire graduates for intermediate-level jobs - at the expense of workers with an intermediate level of education. Consequently, field-specific and general skills would be relevant only to the distribution of graduates across job levels, but not to unemployment. However, this strict interpretation of the crowding out hypothesis ignores that there may be other adjustment mechanisms. Wieling and Borghans (2001), for example, find that for graduates, accepting a job for which no tertiary-level degree is required is only one of the adjustment mechanisms in the labour market. They also find that for some specific fields of study, an increasing oversupply of graduates is associated with an increase in graduate unemployment. This is contrary to what we would expect if the higher educated were always higher skilled and better suited for jobs than the lower educated. Nickell and Bell (1995) suggest that high-skilled workers are only able to crowd out lower skilled workers if they can perform many of the tasks undertaken by the lower skilled. This argument is key to formulating expectations about limitations to the crowding out process in the two labour market segments we distinguish. 
In contrast to general skills, the field-specific skills of the higher educated do not necessarily substitute for the field-specific skills of the medium educated: being a good plumber requires different skills than developing and constructing domestic drainage systems. If the better jobs at the intermediate level are assigned to well trained workers with intermediate levels of education, then some graduates - more precisely those whose level and nature of field-specific skills cannot compete with the level and nature of the field-specific skills of workers with intermediate levels of education - will not be able to find a job, or will be able to find a job acceptable to them in terms of pay and job quality. ${ }^{6}$ Consequently, graduates with low field-specific skills will be more likely to be unemployed than graduates with high field-specific skills, as the latter will be able to find work at an adequately high level. These limitations to graduates' opportunity to crowd out the lower educated are less pronounced in the general labour market. In occupations which require general skills, workers with intermediate levels of education can much more easily be substituted by graduates. In this labour market segment, it is much more attractive for firms to hire graduates instead of workers with intermediate levels of education, as graduates have 'more of the same' skills. In the general labour market, jobs at the intermediate level are thus available for graduates, so even the least skilled graduates find acceptable jobs in terms of pay and job quality (see Fig. 1). General skills thus are related only to the distribution of graduates across job levels, but are unrelated to unemployment.

Figure 1 illustrates how this conceptualisation of the labour market for graduates might look. Graduates entering the labour market can potentially take jobs in two labour market segments, which are subdivided into two levels. Graduates can accept a graduate-level job related to the occupational domain of their field of study or outside this domain (the general labour market). The same applies for intermediate-level jobs. Here, graduates can also take up a job related to the occupational domain of their field of study or in the general labour market. The downward arrow on

\footnotetext{
${ }^{6}$ These graduates might also opt for unemployment because they fear that accepting a low skilled job signals low ability to potential future employers or because they find it more efficient to search for a better job while unemployed (Evans, 1999).
} 
the left side indicates the decreasing level of skill required of these workers. The argument here is that for some intermediate-level jobs in the field-specific occupational domain, the skills highereducated workers bring are not suited (indicated by the diagonally striped area). Consequently, these jobs are not available for graduates despite their higher level of education, leaving some graduates with low field-specific skills unemployed. We therefore expect that high field-specific skills also protect graduates against unemployment (hypothesis 4). We therefore further expect the protective effect of field-specific skills against unemployment to be higher when excess supply of graduates in the respective occupational domain is higher (hypothesis 5). The limitations to graduates' opportunities to crowd out lower-educated workers are expected to be far less pronounced in the general labour market. We therefore expect the protective effect of general skills against unemployment to be significantly weaker than the protective effect of field-specific skills (hypothesis 6). However, here too we might expect that the protective effect of general skills against unemployment to be higher when excess supply of graduates in the general labour market is higher (hypothesis 7). 
Fig. 1. Four labour market segments and available jobs for graduates

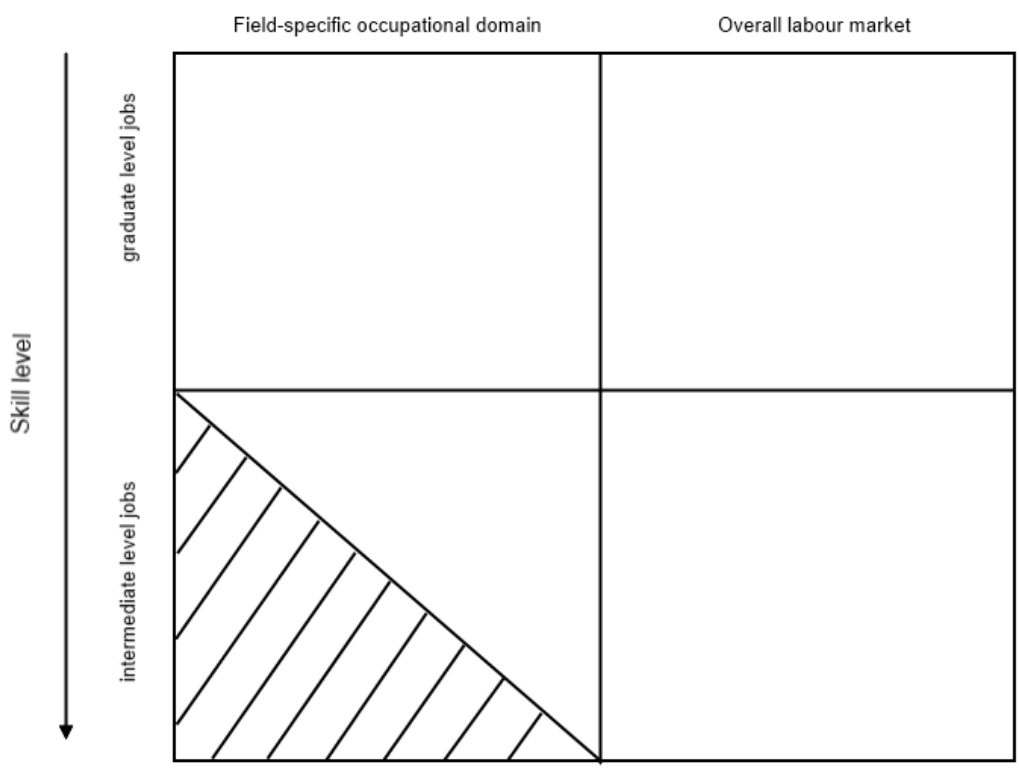

\section{Data}

Our analysis is based on original and representative data from the REFLEX and HEGESCO surveys among graduates from 17 European countries. ${ }^{7}$ The questionnaire was sent to higher education graduates 5 years after graduation. Our sample contains 11,552 individuals for the estimation of the probability of being unemployed, and 11,129 individuals for the estimation of the probability of being overeducated.

In the questionnaire, respondents were asked to rate their level of 19 different skills on a scale from 1 (very low) to 7 (very high). Two of these skills, 'mastery of own field or discipline' and

\footnotetext{
${ }^{7}$ The REFLEX survey (The Flexible Professional in the Knowledge Society) was conducted in 2005 among 15 European countries and Japan. The HEGESCO survey (Higher Education as a Generator of Strategic Competences) is the extension of REFLEX to four new EU member states and Turkey conducted in 2009. In our analysis, we focus only on European countries to ensure comparability. We excluded Sweden and Portugal because their survey design substantially deviated from the rest of the survey. For the remaining countries, we include only individuals who were less than 36 years old at the time of the survey to avoid unobserved pre-university labour market experience influencing the results. Moreover, we exclude all individuals who were not living or working in their home country at the time of the survey or who enrolled in further education after the initial education they reported on. The number of observations per country varies between 382 and 995 .
} 
'analytical thinking' are assumed to indicate field-specific and general skills, respectively. 'Mastery of own field or discipline' refers to graduates' level of theoretical and practical knowledge in their own field and to the ability to apply this knowledge in practice. Analytical thinking, on the other hand, refers to the ability to generalize from a concrete problem to abstract ideas, and to manipulate these ideas to arrive at a solution, not only to the original problem, but to a whole class of similar problems. These skills match our definition of field-specific and general skills quite well.

Our definition of the dependent variables is straightforward. We consider an individual unemployed if that individual had been actively trying to obtain paid work in the four weeks preceding the survey but was not in paid work at the time of the survey. With regard to overeducation, we asked respondents to indicate the type of education most appropriate to their job. ${ }^{8}$ We consider graduates overeducated if the appropriate type of education for their job is below tertiary level.

We use the unemployment rate among graduates at the time of the survey as a proxy for labour market conditions. In order to test our hypotheses, we include two different unemployment rates in our models: (1) the unemployment rate among graduates in the respondent's country, and (2) the unemployment rate among graduates in the respondent's field of study within that country. The former is a good proxy for excess supply in the general labour market, as every unemployed graduate can compete for jobs in the general labour market. The latter is a proxy for excess supply in the occupational domain related to a particular field of study. Due to the specificity of skills required, only graduates of the respective field of study can enter competition for jobs in the occupational domain related to a particular field of study. Both unemployment rates are calculated on the basis of the combined REFLEX and HEGESCO data as posterior means. ${ }^{9}$ Their values per country and field of study are displayed in Table 1. In the probit regressions, we include the

\footnotetext{
${ }^{8}$ For a discussion on measurement issues in assessing overeducation, see Van der Velden and Van Smoorenburg (1997), Dolton and Vignoles (2000) and Hartog (2000).

${ }^{9}$ When using posterior means instead of simple means, the mean country unemployment and the mean field-specific unemployment are corrected for reliability by shifting toward the Grand Mean, depending on the number of observations within each country and field of study.
} 
unemployment rate in the occupational domain of a particular field of study (the field-specific unemployment rate within a country) as the deviation from the overall unemployment rate (the country-level unemployment rate), and we include the overall unemployment rate as the deviation from the unemployment rate of the whole sample. This ensures that both unemployment rates are uncorrelated and brings advantages concerning the interpretation of the regression results, as pointed out in the next section. Note that using international variation for the identification of effects of skills and their interaction with labour market conditions has advantages over national studies, but also obvious limitations. The main advantage is that measures generated from international data offer variation usually unavailable within a single country and provide insight into long-term, general equilibrium effects. A clear limitation of cross-country, cross-field evidence is the possible omission of country-level and field-level variables, such as institutional differences in ability sorting or employers' beliefs. This makes identification of effects less clean than in studies exploiting changes within countries and fields over time.

As control variables, we use only variables which influence the probability of being overeducated or unemployed, because of signalling or network effects, but which are not necessarily outcomes of skills. We include gender, age, age squared, a dummy for whether the father has a higher education, a dummy for whether the respondent had a master's degree or equivalent, ${ }^{10}$ a dummy for whether the respondent had study-related work experience during higher education, and a dummy for whether the respondent had non-study-related work experience during the higher education period. ${ }^{11}$

\footnotetext{
${ }^{10}$ Note that the respondents in the survey completed their study before the Bologna process. Strictly speaking, we are talking about second-level higher education degrees at ISCED level 5A allowing direct access to doctoral studies. For convenience however, we refer to this as a master's degree or equivalent. The reference category is a degree at ISCED level 5A not offering direct access to doctoral studies (usually this is similar to a bachelor's degree).

${ }^{11}$ Descriptive statistics for all variables used in the multivariate analysis can be found in Appendix A. Additional models containing more individual and institutional control variables, such as the graduate's work experience, the country's employment protection legislation, and vocational specificity of the labour market, can be found in Appendix C.
} 
Table 1. Overall unemployment rates and unemployment rates in the occupational domain of particular fields of study per country

\begin{tabular}{lcccccccccc} 
& Mean & ED & HU & SJI & BL & SMC & EMC & AV & HW & SE \\
\hline Austria & 4.3 & 2.4 & 6.1 & 4.4 & 4.5 & 3.6 & 3.2 & 5.8 & 4.8 & 3.7 \\
Belgium & 2.2 & 1.9 & 3.3 & 2.2 & 1.1 & 3.0 & 2.0 & 2.1 & 1.2 & 1.9 \\
Czech Republic & 2.6 & 3.1 & 3.9 & 1.6 & 1.9 & 2.6 & 2.1 & 2.5 & 2.6 & 2.1 \\
Estonia & 1.9 & 1.0 & 2.3 & 1.7 & 1.2 & 1.2 & 1.1 & 2.3 & 2.4 & 2.5 \\
Finland & 4.4 & 4.4 & 4.9 & 3.3 & 4.0 & 4.1 & 3.1 & 3.5 & 5.8 & 6.5 \\
France & 7.6 & 6.6 & 10.5 & 8.7 & 8.2 & 9.7 & 5.7 & 7.2 & 5.9 & 7.5 \\
Germany & 4.8 & 4.7 & 5.9 & 4.7 & 4.1 & 7.3 & 4.6 & 4.1 & 3.8 & 4.0 \\
Hungary & 5.0 & 6.7 & 4.2 & 5.3 & 4.9 & 4.6 & 4.5 & 4.9 & 4.1 & 5.9 \\
Italy & 7.6 & 9.0 & 10.2 & 9.1 & 7.4 & 8.4 & 3.6 & 8.1 & 6.6 & 7.4 \\
Lithuania & 3.2 & 3.8 & 4.4 & 2.7 & 2.7 & 2.8 & 2.7 & - & 2.9 & 3.0 \\
Netherlands & 4.2 & 2.6 & 6.0 & 4.0 & 3.6 & 6.1 & 3.5 & 4.7 & 2.8 & 4.1 \\
Norway & 2.7 & 2.4 & 3.3 & 3.0 & 2.1 & 2.5 & 2.2 & 2.6 & 2.1 & 3.1 \\
Poland & 2.2 & 3.3 & 2.0 & 1.5 & 2.1 & 2.3 & 1.7 & 2.0 & 1.8 & 1.8 \\
Spain & 8.9 & 9.8 & 12.5 & 9.9 & 7.8 & 10.3 & 5.1 & 11.3 & 7.5 & 8.0 \\
Slovenia & 3.8 & 3.9 & 4.1 & 3.3 & 3.6 & 3.5 & 2.4 & 5.1 & 1.6 & 5.4 \\
Switzerland & 4.4 & 3.6 & 5.2 & 5.3 & 4.2 & 6.4 & 3.2 & 4.3 & 3.1 & - \\
United Kingdom & 3.6 & 2.7 & 5.6 & 3.5 & 3.3 & 2.6 & 3.8 & 4.0 & 2.5 & 3.8 \\
\hline
\end{tabular}

Note: Values are posterior means derived from REFLEX/HEGESCO data. ED=Education, HU=Humanities and Arts, $\mathrm{SJI}=$ Social Sciences, Journalism and Information, $\mathrm{BL}=$ Business, Law, $\mathrm{SMC}=$ Science, Mathematics and Computing, EMC=Engineering, Manufacturing and Construction, AV=Agriculture and Veterinary, HW=Health and Welfare, $\mathrm{SE}=$ Services.

\section{Estimation results and discussion}

In this section, we present our estimation results using pooled probit models. For both dependent variables, i.e., the probability of being overeducated as well as the probability of being unemployed, we estimate three models.

In model 1, the labour market mismatch, $M M$, of graduate $i$ is estimated as follows:

$$
\begin{aligned}
& M M_{i}^{*}=\beta_{10}+\beta_{11} \text { spec }_{i}+\beta_{12} \text { gen }_{i}+\beta_{13} u f_{c f}+\beta_{14} u c_{c}+\beta_{15} X_{i}+\varepsilon_{1 i} \\
& M M_{i}=1\left[M M_{i}^{*}>0\right] \\
& \varepsilon_{i} \sim N(0,1),
\end{aligned}
$$

where $M M_{i}$ is either 1 if unemployed or 1 if overeducated, depending on the mismatch examined. $M M_{i}^{*}$ is the latent variable underlying the probability of being unemployed or overeducated. Spec $_{i}$ is the respondent's level of field-specific skills, gen $_{i}$ is the respondent's level of general skills 
(analytical thinking), $u f_{c f}$ is the unemployment rate in the occupational domain of the field of study, $u c_{c}$ is the overall (country-level) unemployment rate, and $X_{i}$ is our vector of controls.

Model 2 (equation 2) is our preferred model which tests our hypotheses. Here, we additionally include the interaction term of field-specific skills with the unemployment rate in the occupational domain of the field of study, specхuf , as well as genхис $_{i}$, the interaction term of general skills with the overall unemployment rate. Negative coefficient $\beta_{21}$ in combination with negative coefficient $\beta_{25}$ would indicate that the protective effect of field-specific skills against unemployment (or overeducation) increases with the degree of excess supply of graduates in the occupational domain of the field of study. Negative coefficient $\beta_{22}$ in combination with negative coefficient $\beta_{26}$ would indicate that the protective effect of general skills against unemployment (or overeducation) increases with the degree of excess supply of graduates in the general labour market.

$$
\begin{aligned}
& M M_{i}^{*}=\beta_{20}+\beta_{21} \text { spec }_{i}+\beta_{22} \text { gen }_{i}+\beta_{23} u_{c f}+\beta_{24} u c_{c}+\beta_{25} \text { specxuf }_{i}+\beta_{26} \text { genxuc }_{i}+ \\
& \beta_{27} X_{i}+\varepsilon_{2 i}
\end{aligned}
$$

Model 3 (equation 3) includes two additional interaction terms between skills and unemployment rates; they test whether field-specific skills also interact with the overall unemployment rate, speсхис ${ }_{i}$, and whether the effect of general skills depends on field-specific labour market conditions, genxuf $_{i .}{ }^{12}$

$$
\begin{aligned}
& \text { MM }_{i}^{*}=\beta_{30}+\beta_{31} \text { spec }_{i}+\beta_{32} \text { gen }_{i}+\beta_{33} u f_{c f}+\beta_{34} u c_{c}+\beta_{35} \text { specxuf }_{i}+\beta_{36} \text { genxuc }_{i}+ \\
& \beta_{37} \text { speсхuс }_{i}+\beta_{38} \text { genxuf }_{i}+\beta_{39} X_{i}+\varepsilon_{3 i}
\end{aligned}
$$

For the interpretation of the coefficients of the main effects of skills in model 2, it is important to keep in mind that the unemployment rate in the occupational domain of a particular field of study is expressed as the deviation from the overall unemployment rate, and that the overall unemployment rate is expressed as the deviation from the unemployment rate of the whole sample. This means that

\footnotetext{
${ }^{12}$ We also ran all six models including field of study dummies; this did not substantially change the results.
} 
the averages of these two variables are each zero. Consequently, the main coefficients of skills in model 2 represent the effect of skills when the respective unemployment rate is average.

\section{Overeducation}

Table 2 presents the estimation results of the models, with the probability of being overeducated for one's job five years after graduation as the dependent variable. Model 1 shows that, on average, both skill types are negatively related to the probability of being overeducated. ${ }^{13}$ For the average person in our sample, a one-standard-deviation increase in field-specific skills reduces the risk of being overeducated by 1 percentage point to $6.1 \%$. A one-standard-deviation increase in general skills reduces the risk of being overeducated by 1.4 percentage points to $5.7 \%$.

Both unemployment rates are positively related to the probability of being overeducated for one's job. Moreover, as expected, both the coefficient of the interaction of general skills ('analytical thinking') and the overall unemployment rate, as well as the coefficient of the interaction of fieldspecific skills ('mastery of own field') and the unemployment rate in the occupational domain of the field of study, are negative and significant at the $5 \%$ level in model 2 . This indicates that when the degree of excess supply of graduates in the general labour market increases, the protective effect of general skills against the risk of overeducation also increases. Similarly, the protective effect of field-specific skills against the risk of overeducation increases when the excess supply of graduates in the occupational domain of the field of study rises.

\footnotetext{
${ }^{13} \mathrm{We}$ also tested whether graduates working in jobs that match their level of education have higher skills because they receive more training than those who are overeducated (Van Smoorenburg and Van der Velden, 2000). We therefore reran our estimation once with hours of training in the past weeks and once with a dummy indicating participation in training in the past 12 months to account for the effect of training on skills. Including these variables did not substantially change the coefficients of our variables of interest, indicating that our skill variables are not picking up training effects.
} 
Table 2. Probability of being overeducated five years after graduation

\begin{tabular}{|c|c|c|c|}
\hline & Model 1 & Model 2 & Model 3 \\
\hline $\begin{array}{l}\text { Mastery of own field } \\
\text { (standardized) }\end{array}$ & $\begin{array}{l}-0.076 * * * \\
(0.019)\end{array}$ & $\begin{array}{l}-0.077 * * * \\
(0.019)\end{array}$ & $\begin{array}{l}-0.077 * * \\
(0.019)\end{array}$ \\
\hline $\begin{array}{l}\text { Analytical thinking } \\
\text { (standardized) }\end{array}$ & $\begin{array}{l}-0.101^{* * *} \\
(0.019)\end{array}$ & $\begin{array}{l}-0.099 * * * \\
(0.019)\end{array}$ & $\begin{array}{l}-0.100 * * * \\
(0.019)\end{array}$ \\
\hline Overall unemployment rate & $\begin{array}{l}0.101 * * * \\
(0.008)\end{array}$ & $\begin{array}{l}0.098 * * * \\
(0.008)\end{array}$ & $\begin{array}{l}0.098 * * * \\
(0.008)\end{array}$ \\
\hline $\begin{array}{l}\text { Unemployment rate in occ. dom. of } \\
\text { field of study }\end{array}$ & $\begin{array}{l}0.073 * * * \\
(0.014)\end{array}$ & $\begin{array}{l}0.070 * * * \\
(0.014)\end{array}$ & $\begin{array}{l}0.070 * * * \\
(0.015)\end{array}$ \\
\hline Overall unemployment rate $\mathrm{X}$ & & $-0.019 * *$ & $-0.021 * *$ \\
\hline Analytical thinking & & $(0.008)$ & $(0.009)$ \\
\hline Unemployment rate in occ.dom. of & & $-0.030 * *$ & $-0.030 * *$ \\
\hline field of study X Mastery of own field & & $(0.014)$ & $(0.015)$ \\
\hline Unemployment rate in occ.dom. of & & & -0.006 \\
\hline field of study X Analytical thinking & & & $(0.015)$ \\
\hline Overall unemployment rate $\mathrm{X}$ & & & 0.006 \\
\hline Mastery of own field & & & $(0.009)$ \\
\hline Controls included & yes & yes & yes \\
\hline Pseudo R-squared & 0.067 & 0.069 & 0.069 \\
\hline $\begin{array}{l}\mathrm{N} \\
\text { Note: Coefficients reported are estimates } \\
\text { parentheses (significance levels ***0.01, ** } \\
\text { Controls included are gender, age, age sq } \\
\text { having a second-level degree, study-related } \\
\text { study-related work experience during higher } \\
\text { Data: REFLEX/HEGESCO. }\end{array}$ & $\begin{array}{l}11129 \\
\text { rom a pooled } \\
.05, * 0.1) \text {. } \\
\text { ared, father hav } \\
\text { ork experience } \\
\text { ducation. }\end{array}$ & $\begin{array}{l}11129 \\
\text { robit, robust stanc } \\
\text { ug higher educatio } \\
\text { uring higher educa }\end{array}$ & $\begin{array}{r}11129 \\
\text { ard errors in } \\
\text { n, respondent } \\
\text { ion, and non- }\end{array}$ \\
\hline
\end{tabular}

Table 3a (for field-specific skills) and Table 3b (for general skills) show the predicted probabilities of being overeducated for different values of skills and unemployment rates, holding all other variables fixed at their means. The probability of being overeducated for graduates with high and low levels of field-specific skills converges when excess supply of graduates in the occupational domain of the field of study is low, and diverges when the degree of slack in this labour market segment rises. Similarly, the probability of being overeducated for graduates with high and low levels of general skills converges when overall excess supply of graduates is low, and diverges when overall excess supply of graduates rises. Our estimation results therefore support our hypotheses. 
Model 3 shows that the interaction term of field-specific skills and the overall unemployment rate, as well as the interaction term of general skills and unemployment in the occupational domain of the field of study, are not statistically significant. This suggests that fluctuations of the unemployment rate in one labour market segment do not affect job competition in the other labour market segment. In other words, the level of protection against the risk of overeducation which field-specific skills offer does not depend on overall excess supply of graduates. Moreover, the level of protection against the risk of overeducation which general skills offer does not vary with the degree of excess supply of graduates in the occupational domain of the field of study.

Table 3a. Probability of being overeducated for different levels of field-specific skills and unemployment in occupational domain of field of study (other variables fixed at mean)

\begin{tabular}{l|c|c|c} 
& $\begin{array}{c}\text { low field- } \\
\text { specific skills } \\
\text { (1 std. dev. } \\
\text { below } \\
\text { average) }\end{array}$ & $\begin{array}{l}\text { high field- } \\
\text { specific skills } \\
\text { (1 std. dev. } \\
\text { above } \\
\text { average) }\end{array}$ & difference \\
\hline $\begin{array}{l}\text { low } \\
\text { unemployment in } \\
\text { occ. domain of a } \\
\text { field of study (2\% } \\
\text { below average) }\end{array}$ & 6.5 & 4.8 & -1.7 \\
\hline $\begin{array}{l}\text { average } \\
\text { unemployment in } \\
\text { occ. domain of a } \\
\text { field of study }\end{array}$ & 8.5 & 6.4 & -2.1 \\
\hline $\begin{array}{l}\text { high } \\
\text { unemployment in } \\
\text { occ. domain of a } \\
\text { field of study (2\% } \\
\text { above average) }\end{array}$ & 11.1 & 8.4 & -2.7 \\
\hline
\end{tabular}


Table 3b. Probability of being overeducated for various levels of general skills and overall unemployment (other variables fixed at mean)

\begin{tabular}{l|c|c|c} 
& $\begin{array}{c}\text { low general } \\
\text { skills (1 std. } \\
\text { dev. below } \\
\text { average) }\end{array}$ & $\begin{array}{l}\text { high general } \\
\text { skills (1 std. } \\
\text { dev. above } \\
\text { average) }\end{array}$ & difference \\
\hline $\begin{array}{l}\text { low overall } \\
\text { unemployment } \\
\left(\begin{array}{l}2 \% \text { below } \\
\text { average) }\end{array}\right.\end{array}$ & 6.3 & 4.2 & -2.1 \\
\hline $\begin{array}{l}\text { average overall } \\
\text { unemployment }\end{array}$ & 9.2 & 6.3 & -2.9 \\
\hline $\begin{array}{l}\text { high overall } \\
\text { unemployment } \\
\begin{array}{l}(2 \% \text { above } \\
\text { average })\end{array}\end{array}$ & 13.1 & 9.3 & -3.8 \\
\hline
\end{tabular}

\section{Unemployment}

Table 4 presents the estimation results for the probability of being unemployed five years after graduation. The estimation results in model 1 show that graduates who have high field-specific skills have a lower probability of being unemployed than those who have a lower level of fieldspecific skills. For the average person in our sample, a one-standard-deviation increase in fieldspecific skills lowers the chance of being unemployed by 0.8 percentage points to $2.2 \% .{ }^{14}$ This finding confirms hypothesis 4 with regard to the protective effect of field-specific skills against unemployment. The coefficients of the interaction terms in neither model 2 nor model 3 are statistically significant. We thus find no support for hypothesis 5 that the protective effect of fieldspecific skills against the risk of unemployment varies with excess supply of graduates in the occupational domain of the field of study.

Further, the protective effect of general skills against unemployment is insignificant, and is significantly weaker than the protective effect of field-specific skills, which confirms hypothesis 6 . Moreover, we do not find that the protective effect of general skills is related to the rate of unemployment. Thus, we find no evidence for hypothesis 7 . These results suggest that firms are always better off hiring graduates instead of workers with intermediate levels of education for jobs which require general skills.

\footnotetext{
${ }^{14}$ For a table with marginal effects see Appendix B.
} 
Table 4. Probability of being unemployed five years after graduation

\begin{tabular}{|c|c|c|c|}
\hline & Model 1 & Model 2 & Model 3 \\
\hline Mastery of own field & $-0.124 * * *$ & $-0.128 * * *$ & $-0.128 * * *$ \\
\hline (standardized) & $(0.025)$ & $(0.025)$ & $(0.025)$ \\
\hline Analytical thinking & 0.029 & 0.026 & 0.025 \\
\hline (standardized) & $(0.024)$ & $(0.024)$ & $(0.025)$ \\
\hline \multirow{2}{*}{ Overall unemployment rate } & $0.088 * * *$ & $0.089 * * *$ & $0.089 * * *$ \\
\hline & $(0.011)$ & $(0.011)$ & $(0.011)$ \\
\hline Unemployment rate in occ. dom. of & $0.167 * * *$ & $0.168 * * *$ & $0.169 * * *$ \\
\hline field of study & $(0.019)$ & $(0.019)$ & $(0.019)$ \\
\hline Overall unemployment rate $\mathrm{X}$ & & 0.014 & 0.011 \\
\hline Analytical thinking & & $(0.010)$ & $(0.012)$ \\
\hline Unemployment rate in occ.dom. of & & 0.016 & 0.012 \\
\hline field of study X Mastery of own field & & $(0.018)$ & $(0.019)$ \\
\hline Unemployment rate in occ.dom. of & & & 0.008 \\
\hline field of study X Analytical thinking & & & $(0.020)$ \\
\hline Overall unemployment rate $\mathrm{X}$ & & & 0.005 \\
\hline Mastery of own field & & & $(0.011)$ \\
\hline Controls included & yes & yes & yes \\
\hline Pseudo R-squared & 0.067 & 0.068 & 0.068 \\
\hline $\mathrm{N}$ & 11552 & 11552 & 11552 \\
\hline \multicolumn{4}{|c|}{$\begin{array}{l}\text { Note: Coefficients reported are estimates from a pooled probit procedure; robust standard } \\
\text { errors in parentheses (significance levels } * * 0.01, * * 0.05, * 0.1 \text { ). }\end{array}$} \\
\hline \multicolumn{4}{|c|}{$\begin{array}{l}\text { Controls included: gender, age, age squared, father having higher education, respondent } \\
\text { having a second-level degree, study-related work experience during higher education, and } \\
\text { non-study-related work experience during higher education. } \\
\text { Data: REFLEX/HEGESCO. }\end{array}$} \\
\hline
\end{tabular}

\section{Conclusion}

This paper focuses on two dimensions of the crowding out hypothesis by investigating the relationship between graduates' skills and the risk of being employed in a job for which no tertiary degree is required, or being unemployed.

We find that competition for graduate jobs is related to skills, and this relationship intensifies with the degree of excess supply of graduates.

We establish a conceptual framework in which two labour market domains are distinguished: a labour market domain where field-specific skills determine the allocation of graduates to jobs (the occupational domain of a particular field of study), and a labour market domain where general skills determine the allocation of graduates to jobs (the general labour market). In line with the crowding 
out hypothesis, we find that the protective effect of field-specific skills against the risk of overeducation depends on the degree of excess supply of graduates in the occupational domain of the corresponding field of study, and that the protective effect of general skills against overeducation depends on the degree of excess supply of graduates in the general labour market.

In line with a conceptual framework which deviates from strict interpretation of the crowding hypothesis, and which incorporates the idea that the substitutability of the field-specific skills of graduates and the field-specific skills of workers with intermediate levels of education is subject to substantial limitations, we find that graduates with low field-specific skills have a higher probability of being unemployed than graduates with high field-specific skills. We do not find this effect for general skills, supporting the idea that field-specific skills of graduates and lower-educated workers can differ in nature, but we do find that the general skills of graduates and lower-educated workers can be characterized as 'more of the same'.

The results of this study are encouraging and give new insight into the workings of the labour market for graduates. We realize, however, that using cross-sectional data to test our conceptual framework can be only a first step. Further research exploiting cyclical variation within fields and within countries over time is needed to better establish causality. 


\section{References}

Allen, J. and Van der Velden, R. (2001) Educational mismatches versus skill mismatches: effects on wages, job satisfaction, and on-the-job search, Oxford Economic Papers, 53, 434-52.

Ai, C. and Norton, E. C. (2003) Interaction terms in logit and probit models, Economics Letters, 80, 123-29.

Bishop, J. (1995) Expertise and Excellence, CAHRS Working Paper Series No. 95-13, Cornell University, Ithaca, NY.

Battu, H., Belfield, C. R. and Sloane, P. J. (1999) Overeducation among graduates: a cohort view, Education Economics, 7, 21-38.

Battu, H. and Sloane, P.J. (2000) Overeducation and Crowding out in Britain, in The overeducated worker? The economics of skill utilization, (Eds.) L. Borghans and A. De Grip, Edgar Elgar Cheltenham, UK/Northampton, pp.157-74.

Borghans, L. and De Grip, A. (2000) The overeducated worker? The economics of skill utilization, Edgar Elgar, Cheltenham, UK/Northampton.

Campbell, P. B. and Laughlin, S. (1991) Participation in Vocational Education: An Overview of Patterns and their Outcomes, in National Center for Research in Vocational Education: Columbus, $\mathrm{OH}$.

Chevalier, A. (2003) Measuring over-education, Economica, 70, 509-33.

Chevalier, A. and Lindley, J. (2009) Overeducation and the skills of UK graduates, Journal of the Royal Statistical Society: Series A (Statistics in Society), 172, 307-37.

Devereux, P. J. (2002) Occupational Upgrading and the Business Cycle, Labour, 16, 423-52.

Di Pietro, G. and Urwin, P. (2006) Education and skills mismatch in the Italian graduate labour market, Applied Economics, 38, 79-93.

Dolton, P. and Vignoles, A. (2000) The incidence and effects of overeducation in the U.K. graduate labour market, Economics of Education Review, 19, 179-98.

Evans, P. (1999) Occupational Downgrading and Upgrading in Britain, Economica, 66, 79-96.

Gautier, P. A., Van den Berg, G., Van Ours, G.C. and Ridder, G. (2002) Worker turnover at the firm level and crowding out of lower educated workers, European Economic Review, 46, 523-38.

Gesthuizen, M. and Wolbers, M. H. J. (2010) Employment transitions in the Netherlands, 19802004: Are low educated men subject to structural or cyclical crowding out?, Research in Social Stratification and Mobility, 28, 437-51.

Goux, D. and Maurin, E. (1994) Education, Expérience et Salaire: Tendances Recentes et Evolution de Long Terme, Economie et Prévision, 116, 155-78.

Green, F. and McIntosh, S. (2007) Is there a genuine under-utilization of skills amongst the overqualified?, Applied Economics, 39, 427-39.

Hartog, J. (2000) Over-education and earnings: where are we, where should we go?, Economics of Education Review, 19, 131-47.

Heijke, H., Meng, C. and Ris, C. (2003) Fitting to the job: the role of generic and vocational competencies in adjustment and performance, Labour Economics, 10, 215-29.

Kang, S. and Bishop, J. (1989), Vocational and academic education in high school: Complements or substitutes?, Economics of Education Review, 8, 133-48.

Keane, M. and Prasad, E. (1993) Skill Levels and the Cyclical Variability of Employment, Hours, and Wages, Staff Papers - International Monetary Fund, 40, 711-43.

Mane, F. (1999) Trends in the payoff to academic and occupation-specific skills: the short and medium run returns to academic and vocational high school courses for non-college-bound students, Economics of Education Review, 18, 417-37.

McGuinness, S. (2003) Graduate overeducation as a sheepskin effect: Evidence from Northern Ireland, Applied Economics, 35, 597-608. 
McGuiness, S. and Sloane, P.J. (2010) Labour market mismatch among UK graduates: An analysis using REFLEX data, Economics of Education Review, 30, 130-45.

Nickell, S. and Bell, B. (1995) The collapse in demand for the unskilled and unemployment across the OECD, Oxford Review of Economic Policy, 11, 40-62.

Payne, J. (1995) Options at 16 and Outcomes at 24: a Comparison of Academic and Vocational Education and Training Routes, in Youth Cohort Report 35, Department for Education and Employment, Sheffield.

Pollmann-Schult, M. (2005) Crowding-out of Unskilled Workers in the Business Cycle: Evidence from West Germany, European Sociological Review, 21, 467-80.

Ryan, P. (2001) The School-to-Work Transition: A Cross-National Perspective, Journal of Economic Literature, 39, 34-92.

Sloane, P. J., Battu, H. and Seaman, P. T. (1996) Overeducation and the formal education/experience and training trade-off, Applied Economics Letters, 3, 511-15.

Sloane, P., Battu, H. and Seaman, P. (1999) Overeducation, undereducation and the British labour Market, Applied Economics, 31, 1437-53.

Teulings, C. and Koopmanschap, M. (1989) An econometric model of crowding out of lower education levels, European Economic Review, 33, 1653-64.

Thurow, L. C. (1975) Generating Inequality, Basic Books, New York.

Van Ours, J. C. and Ridder, G. (1995) Job matching and job competition: Are lower educated workers at the back of job queues?, European Economic Review, 39, 1717-31.

Van der Velden, R.K.W. and Van Smoorenburg M.S.M. (1997) The Measurement of Overeducation and Undereducation: Self-Report vs. Job-Analyst Method, Research Centre for Education and the Labour Market Research Memorandum 1997/2E, Maastricht.

Van Smoorenburg, M. S. M. and Van der Velden, R. K. W. (2000) The training of school-leavers: Complementarity or substitution?, Economics of Education Review, 19, 207-17.

Verhaest, D. and Van der Velden, R. K. W. (2010) Cross-country differences in graduate overeducation and its persistence, Research Centre for Education and the Labour Market Research Memorandum 2010/7, Maastricht. 


\section{Appendix A}

Descriptives of variables used in multivariate analysis (overeducation model)

\begin{tabular}{|c|c|c|c|c|c|c|c|c|}
\hline & \multirow[t]{2}{*}{ obs } & \multirow[t]{2}{*}{$\%$ overeducated } & \multicolumn{2}{|c|}{ Mastery of own field or discipline* } & \multicolumn{2}{|c|}{ Analytical thinking* } & \multicolumn{2}{|c|}{ age } \\
\hline & & & mean & std. dev & mean & std. dev & mean & std. dev \\
\hline Austria & 520 & 10.9 & 5.8 & 0.9 & 5.8 & 1.2 & 31.6 & 0.09 \\
\hline Belgium & 457 & 3.0 & 5.2 & 0.9 & 5.4 & 1.1 & 28.2 & 0.06 \\
\hline Czech Republic & 943 & 2.9 & 5.6 & 1.0 & 5.5 & 1.1 & 28.6 & 0.05 \\
\hline Estonia & 392 & 1.8 & 5.0 & 0.9 & 5.3 & 1.1 & 30.0 & 0.10 \\
\hline Finland & 794 & 6.7 & 5.0 & 1.0 & 4.9 & 1.2 & 30.5 & 0.07 \\
\hline France & 552 & 5.2 & 5.1 & 1.0 & 5.2 & 1.0 & 28.2 & 0.07 \\
\hline Germany & 687 & 5.9 & 5.8 & 0.9 & 5.6 & 1.2 & 31.7 & 0.07 \\
\hline Hungary & 648 & 16.1 & 5.0 & 1.1 & 5.0 & 1.3 & 29.0 & 0.07 \\
\hline Italy & 843 & 14.7 & 5.2 & 1.1 & 5.5 & 1.2 & 31.5 & 0.06 \\
\hline Lithuania & 382 & 5.2 & 5.1 & 1.1 & 5.2 & 1.1 & 28.7 & 0.10 \\
\hline Netherlands & 842 & 6.4 & 5.3 & 0.9 & 5.4 & 1.1 & 29.1 & 0.06 \\
\hline Norway & 804 & 4.4 & 5.3 & 0.9 & 4.7 & 1.4 & 31.4 & 0.07 \\
\hline Poland & 697 & 4.0 & 4.9 & 1.2 & 5.2 & 1.3 & 29.6 & 0.05 \\
\hline Spain & 622 & 18.5 & 5.2 & 1.1 & 4.9 & 1.3 & 29.8 & 0.09 \\
\hline Slovenia & 995 & 10.7 & 5.2 & 1.2 & 5.2 & 1.2 & 30.8 & 0.06 \\
\hline Switzerland & 778 & 10.3 & 5.4 & 0.9 & 5.6 & 1.1 & 31.0 & 0.07 \\
\hline United Kingdom & 568 & 17.2 & 5.1 & 1.1 & 5.3 & 1.2 & 27.6 & 0.07 \\
\hline Total & 11524 & 8.6 & 5.3 & 1 & 5.3 & 1.2 & 30.0 & 0.02 \\
\hline
\end{tabular}


Descriptives of variables used in multivariate analysis (overeducation model), concluded

\begin{tabular}{lccccc} 
& \% female & $\begin{array}{c}\text { \% with higher } \\
\text { educated } \\
\text { father }\end{array}$ & $\begin{array}{c}\text { \% with study } \\
\text { relevant work } \\
\text { experience during } \\
\text { higher education }\end{array}$ & $\begin{array}{c}\text { \% with non-study } \\
\text { relevant work } \\
\text { experience during } \\
\text { higher education }\end{array}$ & $\begin{array}{c}\text { \% second } \\
\text { level degree }\end{array}$ \\
\hline Austria & 49.1 & 21.8 & 71.1 & 63.3 & 89.5 \\
Belgium & 51.7 & 46.6 & 19.8 & 58.0 & 58.6 \\
Czech Republic & 49.3 & 34.0 & 45.9 & 66.6 & 88.0 \\
Estonia & 67.6 & 58.1 & 55.0 & 38.2 & 11.1 \\
Finland & 56.4 & 21.1 & 67.2 & 52.3 & 47.3 \\
France & 69.8 & 39.0 & 57.9 & 55.9 & 36.8 \\
Germany & 46.7 & 59.6 & 58.6 & 46.9 & 59.5 \\
Hungary & 62.0 & 24.8 & 29.3 & 37.7 & 35.5 \\
Italy & 53.2 & 16.6 & 17.9 & 37.4 & 92.2 \\
Lithuania & 63.6 & 42.1 & 37.3 & 43.1 & 34.3 \\
Netherlands & 60.6 & 38.1 & 37.4 & 71.9 & 27.5 \\
Norway & 57.0 & 46.9 & 55.5 & 54.4 & 37.5 \\
Poland & 56.8 & 27.8 & 24.5 & 36.7 & 67.6 \\
Spain & 64.5 & 21.0 & 19.6 & 32.0 & 58.8 \\
Slovenia & 69.0 & 24.1 & 58.2 & 67.0 & 4.2 \\
Switzerland & 37.0 & 46.9 & 50.2 & 45.1 & 61.0 \\
United Kingdom & 56.6 & 34.5 & 18.7 & 43.2 & 5.9 \\
Total & 56.7 & 34.1 & 43.2 & 51.1 & 49.3 \\
\hline
\end{tabular}




\section{Appendix B}

\section{Marginal effects evaluated at sample means}

Marginal effect

\begin{tabular}{ll}
\hline Unemployment & \\
Mastery of own field & $-0.008^{* * *}$ \\
(standardized) & $(0.002)$ \\
Analytical thinking & 0.002 \\
& $(0.002)$ \\
& \\
Overeducation & \\
Mastery of own field & $-0.010^{* * *}$ \\
(standardized) & $(0.003)$ \\
Analytical thinking & $-0.014^{* * *}$ \\
(standardized) & $(0.002)$ \\
Overall unemployment rate X & $-0.005^{* * *}$ \\
Analytical thinking & $(0.001)$ \\
Field-specific unemployment rate X & $-0.005^{* * *}$ \\
Mastery of own field or discipline & $(0.002)$
\end{tabular}

Note: All marginal effects are calculated on the basis of the pooled probit procedure used for producing tables 2 and 3 . The marginal effects of the interaction terms were calculated using the Ai and Norton (2003) inteff stata programme. Controls included are a dummy for being female, age, age squared, a dummy equal to one if father has higher education, a dummy equal to one if respondent has a second level degree, a dummy equal to one if respondent had study related work experience during higher education, and a dummy equal to one if respondent had non-study related work experience during higher education.

Predicted probability of being unemployed at sample mean (mean of all variables):

$\operatorname{Pr}($ Unemployed $\mid \bar{X})=0.030$

Predicted probability of being overeducated at sample mean (mean of all variables):

$\operatorname{Pr}($ Overeducated $\mid \bar{X})=0.071$ 


\section{Appendix C}

\section{Probit regression results with extended set of controls}

DV: Overeducated 5 years after graduation

Model 1

Female

$0.115^{* * *}$

$(0.038)$

Model2

Model3

Age

$-0.119$

$0.117 * * *$

$0.118^{* * * *}$

$(0.190)$

$0.038)$

$(0.038)$

Age squared

0.003

$-0.093$

Father with higher education

$(0.003)$

$-0.154 * * *$

0.002

$(0.191)$

$(0.040)$

Second level degree

$-0.382 * * *$

$(0.039)$

$-0.226^{* * *}$

(0.003)

0.002

$(0.003)$

Study related work during higher education

$(0.038)$

$0.077^{* *}$

$-0.156^{* * *}$

$-0.155^{* * *}$

(0.040)

$(0.040)$

Non-study related work during education

$(0.036)$

$-0.382 * *$

$-0.382 * * *$

(0.039)

(0.039)

Months employed since graduation

$-0.008 * * *$

$-0.226^{* * *}$

$-0.226^{* * *}$

(0.038)

(0.038)

Vocational orientation (country)

$(0.001)$

$0.073 * *$

$0.073^{* *}$

(0.036)

(0.036)

Vocational orier

Employment protection legislation (country)

(0.048)

$-0.008^{* * *}$

$-0.008^{* * *}$

$(0.001)$

$(0.001)$

$-0.255^{* * *}$
$(0.030)$

(0.048)

$0.093 *$

$-0.255^{* * *}$

$(0.048)$

Mastery of own field (standardized)

$-0.073 * * *$
$(0.020)$

(0.030)

$-0.256 * * *$

$-0.074 * * *$

(0.030)

Analytical thinking (standardized)

$-0.099 * * *$

$(0.020)$

$-0.074 * * *$

(0.019)

$-0.097 * * *$

$(0.020)$

$0.104 * * *$
$(0.010)$

(0.019)

$-0.097 * * *$

Overall unemployment rate

$0.101 * * *$

(0.019)

Unemployment rate in occ. dom. of

$0.061 * * *$

(0.010)

$0.101 * * *$

(0.014)

$0.058^{* * *}$

$(0.010)$

field of study

(0.015)

$0.057 * * *$

Overall unemployment rate $\mathrm{x}$

$-0.021 * *$

$(0.009)$

$-0.032 * *$

$(0.015)$

Analytical thinking

Overall unemployment rate $\mathrm{x}$

(0.014)

$-0.023 * *$

Mastery of own field

Unemployment rate in occ. dom of

field of study x Analytical thinking

Unemployment rate in occ. dom of

field of study x Mastery of own field

$-0.032 * *$

$(0.015)$

$-0.006$

(0.015)

0.008

(0.009)

Constant

0.830

0.492

0.441

(2.859)

(2.867)

(2.867)

pseudo-R-squared

0.082
11129

0.084

0.084

Note: Coefficients reported are pooled probit estimates, robust standard errors in parentheses (significance levels $* * * 0.01, * * 0.05, * 0.1$ ).

The vocational orientation index was created by calculating the country average of the vocational orientation of the study programme variable. This worked better than the official OECD statistic referring to the percentage of students in vocational education.

Data: REFLEX/HEGESCO. 